DOI 10.15826/Lurian.2020.1.1.2

УДК 159.9(051.2)

\title{
Greetings From the Lomonosov Moscow State University
}

\author{
Yuri P. Zinchenko \\ President of the Russian Psychological Society, \\ President of the Russian Academy of Education, the Head of Department of psychology, \\ Lomonosov Moscow State University, \\ Russia, Moscow
}

\section{Приветствие от Московского государственного университета}

\author{
Юрий П. Зинченко \\ Президент Российского психологического общества, \\ президент Российской академии образования, декан факультета психологии, \\ Московский государственный университет имени М. В. Ломоносова, \\ Россия, Москва
}

Corresponding author.E-mail:adm.psy@mail.ru

\section{Dear colleagues, \\ I am pleased to welcome you in the issue of the Lurian Journal!}

\author{
Уважаемые коллеги, \\ приветствую вас \\ на страницах “Lurian Journal"!
}

Release of a new journal is a remarkable event for the scientific community. But the first issue of the Lurian journal is particularly noteworthy, since it springs into existence in the dramatic COVID-19 pandemic context!

We can't but agree that a certain professional continuity can be observed in it. Likewise, during WW2, psychologists did not stand aside from the common cause. Many of them made an invaluable contribution to the Victory, using psychological research findings to solve urgent applied issues set by wartime. Among them was Alexander Romanovich Luria, who gained
Выпуск нового журнала - яркое событие в жизни научного сообщества. Но именно первый номер "Lurian Journal” хочется отметить особо, так как он появился в непростой для всего мира ситуации пандемии COVID-19!

Согласитесь, что в этом усматривается некоторая профессиональная преемственность. Так, в годы Великой Отечественной войны не остались в стороне от общего дела и психологи. Многие из них внесли неоценимый вклад в достижение победы, применяя психологические разработки и результаты психологических исследований 
a worldwide recognition as a founder of the Soviet neuropsychological school.

He wrote: "The whole country was seized by a spirit of shared responsibility and common goal. Each of us knew that we had to unite with our compatriots in order to confront the mortal danger. Each of us had to find one's own place in this struggle - either to defend our country on the battlefield, or work in the defense industry that was evacuated to remote areas of the country, or restore health and working ability of the wounded" (Luria A. R. (1982). The Stages Gone Through: A Scientific Autobiography (p. 129). Moscow: Publ. MSU). In the first months of the war in the Southern Urals, in the settlement of Kisegach near Chelyabinsk, Alexander Romanovich was a head of the home front neurosurgical rehabilitation hospital.

Today, in the current pandemic situation, Lurian neuropsychologists work together with doctors in neurological clinics which are redesigned to provide medical care to patients with COVID-19. Armed with the achievements of the Russian School of Psychology laid by L. S. Vygotsky - A. N. Leontiev - A. R. Luria, they study the negative psychological phenomena caused by the pandemic; develop clinical recommendations for patients, their relatives, medical workers, psychologists themselves, that help to cope with the negative effects of coronavirus infection; provide counselling for all target groups that are most vulnerable to the pandemic.

In this situation, my colleagues and I (A. Sh. Tkhostov, V. V. Drummer, N. A. Varako, A. A. Skvortsov, M.S. Kovyazin) had the opportunity to unite ef- в решении важнейших прикладных задач, поставленных военным временем. Среди них был и известный сегодня во всем мире основатель советской нейропсихологической школы Александр Романович Лурия.

Он писал: “Чувство общей ответственности и общей цели охватило всю страну. Каждый из нас знал, что мы обязаны объединиться с нашими соотечественниками, чтобы противостоять смертельной опасности. Каждый из нас должен был найти свое место в этой борьбе - или непосредственно защищая свою страну, или работая в оборонной промышленности, которая была эвакуирована в отдаленные районы страны, или восстанавливая здоровье и трудоспособность раненых" (Лурия А. Р. Этапы пройденного пути : науч. биогр. М. : Изд-во МГУ, 1982. С. 129). В первые месяцы войны на Южном Урале, в маленьком поселке Кисегач близ Челябинска под руководством Александра Романовича был организован тыловой восстановительный госпиталь нейрохирургического профиля.

Так и сегодня, в сложившейся пандемической ситуации, нейропсихологи работают вместе с другими врачами в неврологических клиниках, перепрофилированных под оказание медицинской помощи пациентам с COVID-19. Вооруженные знаниями отечественной психологической школы Л.С. Выготского - А. Н. Леонтьева - А. Р. Лурия, они занимаются изучением негативных психологических феноменов, вызванных пандемией; разрабатывают клинические рекомендации для пациентов, их родственников, медицинских работников и самих психологов, помогающих пре- 
forts and render assistance to the team of doctors and psychologists of the Federal State Budgetary Institution "Federal Center for Brain and Neurotechnology FMBA", under the direction of V. V. Belousova and R. T. Tairova. As in those far-off wartime years, doctors again turned to psychologists for help to overcome various difficulties that arose or escalated during the epidemic. It included assistance to medical workers who face the most severe stress resulting from the changing working environment; to their relatives (including children and the older generation), who are in constant suspenseful wait to meet their loved ones working in dangerous conditions and fear for their life and health; to patients who face uncertainty caused by the serious disease; to their relatives who are unable to communicate with their family members and medical staff; to many other categories of people that need psychological assistance.

I am very grateful to the entire staff of the Center for the unique experience that the psychologists of Moscow State University named after M. V. Lomonosov acquired while exercising their professional duty in the adverse and unpredictable situation of the pandemic.

Rapid changes in the living conditions of modern society that include a wide spread of digital technologies, the use of artificial intelligence, increased informatization, virtualization alongside with uncertainty, turbulence and social polyphonism create new challenges for psychologists. A scope of these challenges is vast: from the development and implementation of new ethical standards, risk assessment and forecasting of a person's socialization up to creating unique opportunities for solving одолевать негативные последствия коронавирусной инфекции; осуществляют консультативную работу для всех целевых групп, которые оказались наиболее уязвимыми для последствий пандемии.

В этой ситуации мне и моим коллегам (А.Ш. Тхостову, В. В. Барабанщиковой, Н.А. Варако, А. А. Скворцову, М. С. Ковязиной) также довелось помогать коллективу врачей и психологов Федерального центра мозга и нейротехнологий под руководством В.В. Белоусова и Р.Т. Таировой. Как и в далекие военные годы, врачи вновь обратились за помощью к психологам для преодоления различных трудностей, которые возникли или обострились на фоне эпидемии: это и помощь медицинским работникам, испытывающим тяжелейший стресс в результате изменившихся условий труда, и их родным (в том числе детям и старшему поколению), находящимся в постоянном напряженном ожидании встречи со своими работающими в опасных условиях близкими и страхе за их жизнь и здоровье, и пациентам, оказавшимся в ситуации неопределенности тяжелого заболевания, и родственникам пациентов, не имеющим возможности для обычного человеческого общения с близкими и с медицинским персоналом, и многим другим категориям людей, нуждающимся в психологической помощи.

Я очень признателен всему коллективу Центра за тот уникальный опыт, который приобрели психологи МГУ, осуществляя свой профессиональный долг в непростой и непредсказуемой ситуации пандемии.

Стремительно меняющиеся условия жизни современного общества - активное распространение цифровых техно- 
fundamental scientific issues which refer to the functioning of consciousness, developing methodological foundations for new scientific areas (i. e., safety psychology, cyberpsychology). The most topical issues comprise high-tech cognitive research, the use of new methods of data processing, including large database analysis. The pandemic situation has reinforced the relevance of Psychological Science for the development of innovative practical and managerial solutions in the sphere of neuropsychology and psychological assistance in general. In this respect it is important to note that the Lurian Journal aims to determine the development prospects and new directions of modern neuroscience and psychology.

It is remarkable that the journal seeks to respond to the urgent needs of the interdisciplinary and multidisciplinary research; plans to publish original theoretical and experimental papers in the fields of cognitive psychology, general, social and educational psychology, psychophysiology and clinical psychology, bio- and neuromedicine, neuroscience; focuses on uniting scientific efforts of the leading researchers and world-class experts in the sphere of psychological sciences and neurotechnologies.

I feel confident that the available scientific potential of the followers of the outstanding Russian neuropsychologist, A. R. Luria, and our unique shared experience of psychological follow-up in COVID-19 pandemic will contribute to enhancing the Journal status as well as opening up new worldwide horizons for the Russian School of Neuropsychology. логий, использование искусственного интеллекта, возрастающая информатизация, виртуализация, неопределенность, турбулентность и социальный полифонизм, ставят перед специалистами в области психологии серьезные вызовы: от разработки и внедрения новых этических норм, оценки и прогноза рисков цифровой социализации человека до уникальных возможностей решения фундаментальных научных вопросов функционирования сознания, разработки методологических основ новых научных направлений (например, психология информационной безопасности, киберпсихология). Актуальными становятся высокотехнологичные когнитивные исследования, использование новых методов обработки данных, в том числе анализа больших баз данных. И ситуация пандемии только усилила актуальность психологической науки, ее востребованность для разработки инновационных практических и управленческих решений в области нейропсихологии и психологической помощи в целом. И здесь важно отметить, что "Lurian Journal" ставит своей целью именно определение перспектив развития и новых направлений современной нейронауки и психологии.

Примечательно, что журнал, отвечая актуальным запросам междисциплинарных и мультидисциплинарных исследований, планирует публикации оригинальных теоретических и экспериментальных работ в областях когнитивной психологии, общей, социальной и педагогической психологии, психофизиологии и клинической психологии, био- и нейромедицины, нейронауки, что, несомненно, будет способствовать консолидации научного поиска ведущих 
исследователей и специалистов мирового уровня в области психологических наук и нейротехнологий.

Уверен, что имеющийся научный потенциал последователей великого отечественного нейропсихолога А. Р. Лурия и наш совместный уникальный опыт психологического сопровождения в условиях пандемии COVID-19 позволят не только повысить статус журнала, но и вывести отечественную нейропсихологическую школу на новый мировой уровень.

Original manuscript received June 26, 2020 Revised manuscript accepted June 27, 2020

To cite this article: Zinchenko, Yu. P. (2020). Greetings from the Lomonosov Moscow State University. Lurian Journal, 1 (1), 13-17. DOI: 10.15826/Lurian.2020.1.1.2 